\title{
Thrombospondins function as regulators of angiogenesis
}

\author{
Paul Bornstein
}

Received: 5 June 2009 / Accepted: 30 July 2009 / Published online: 2 October 2009

(C) The Author(s) 2009. This article is published with open access at Springerlink.com

\begin{abstract}
Thrombospondins (TSPs) -1 and -2 were among the first protein inhibitors of angiogenesis to be identified, a property that was subsequently attributed to the interactions of sequences in their type I repeats with endothelial cellsurface receptors. The interactions of TSPs- 1 and -2 with cell-surface receptors, proteases, growth factors, and other bioactive molecules, coupled with the absence of direct structural functions that can be attributed to these matrix proteins, qualify them for inclusion in the category of 'matricellular proteins'. The phenotypes of TSP-1, TSP-2, and double TSP-1/2-null mice confirm the roles that these proteins play in the regulation of angiogenesis, and provide clues to some of the other important functions of these multi-domain proteins. One of these functions is the ability of TSP- 1 to activate the latent TGF $\beta 1$ complex, a property that is not shared by TSP-2. A major pathway by which TSP1 or TSP2 inhibits angiogenesis involves an interaction with CD 36 on endothelial cells, which leads to apoptosis of both the liganded and adjacent cells. However a homeostatic mechanism, which inhibits endothelial cell proliferation, and may be physiologically preferable under some circumstances, has also been elucidated, and involves interaction with the very low density lipoprotein receptor (VLDLR). The interaction of TSP1with its receptor, CD47, further inhibits angiogenesis by antagonizing nitric oxide signaling in endothelial and vascular smooth muscle cells.
\end{abstract}

\footnotetext{
P. Bornstein $(\triangle)$

Departments of Biochemistry and Medicine,

University of Washington,

Seattle WA 98195, USA

e-mail: bornsten@u.washington.edu

Present Address:

P. Bornstein

P.O. Box 219, Tesuque, NM 87574, USA
}

Paradoxically, there is also evidence that TSP-1 can function to promote angiogenesis. This apparent contradiction can be explained by the presence of sequences in different domains of the protein that interact with different receptors on endothelial cells. The anti-angiogenic function of TSPs has spurred interest in their use as anti-tumor agents. Currently, peptide mimetics, based on sequences in the type I repeats of TSPs that have been shown to have anti-angiogenic properties, are undergoing clinical testing.

Keywords Angiogenesis · Anti-angiogenic therapy CD36 receptor $\cdot$ Homeostatic function $\cdot$ Knockout mice . Matricellular . Nitric oxide $\cdot$ Peptide mimetics . Pro-apoptotic mechanism · Thrombospondin . VLDL receptor
Abbreviations
EC endothelial cells
ECM extracellular matrix
FGF2 fibroblast growth factor 2
IAP Integrin-associated protein
MMP matrix metalloproteinase
NO nitric oxide
TSP thrombospondin
TGF $\beta 1$ transforming growth factor $\beta 1$
VLDL very low density lipoprotein
VLDLR VLDL receptor

\section{Introduction}

The term 'thrombospondin' (TSP) was coined by Jack Lawler and coworkers to identify a protein that was released and purified from thrombin-treated platelets (Lawler et al. 
1977, 1978). The protein was concentrated in the 'particulate' fraction of platelets, now known to contain the $\alpha$ granules, and was shown to be composed of three disulfide-bonded chains, with a total molecular mass of over $4.5 \times 10^{5}$ daltons. These studies expanded and corrected earlier work by Baenziger et al. (1971, 1972) who had identified a 'thrombin-sensitive protein' in platelets. However, exposure of purified thrombospondin (TSP) to thrombin failed to show significant sensitivity to this enzyme (Lawler et al. (1978). Subsequently, TSP, now known as TSP-1, was shown to be synthesized and secreted by a wide variety of cells in culture, including aortic, venous, capillary, and corneal endothelial cells (EC; McPherson et al. 1981; Sage et al. 1981; Mosher et al. 1982), and by fibroblasts (Jaffe et al. 1983) and smooth muscle cells (Raugi et al. 1982).

The TSP 'family' consists of five members (Fig. 1). A second expressed gene was detected by the sequencing of a mouse genomic clone. The sequence was clearly homologous to that of the human TSP gene, but when the corresponding mouse cDNA was sequenced it was evident that the cDNA was the product of a different gene, Thbs2, encoding TSP-2 (Bornstein et al. 1991). A third member of the TSP family, TSP-3, was identified shortly thereafter, in both the human and mouse genomes, as a consequence of its close proximity to the MUC1/mucl genes, encoding human and mouse episialin, respectively. Less than 3 kilobases separate the two genes in both genomes (Vos et al. 1992).

The structures of all five TSPs are shown schematically in Fig. 1. As can be seen, TSP-3 differs from TSP-1 and TSP-2 in lacking the procollagen homology domain and the three type I repeats. Because the type I repeats play a major role in the anti-angiogenic properties of TSPs 1 and 2, it is not surprising that TSP-3 appears to lack this function ( see review by Hankenson and Delany in this issue). A fourth TSP, TSP-4, was first identified by Lawler and coworkers in Xenopus, and subsequently in human tissues (Lawler et al. 1993). Its molecular structure is similar to that of TSP-3 (Fig. 1). While single nucleotide polymorphisms in TSP-4 have been reported to be associated with coronary artery disease in some Western populations (Stenina et al. 2004), there is currently no evidence for an anti-angiogenic function for this protein. Finally, cloning and sequence analysis of cartilage oligmeric matrix protein (COMP; Oldberg et al. 1992; Hedblom et al. 1992) revealed it to be a member of the TSP family, and homologous to TSP-3 and TSP-4 (Fig. 1). Although the term, COMP, is still used frequently in the literature, the protein is also expressed in tendon, ligament, and blood vessels, in addition to cartilage. Therefore, the term TSP-5 seems more appropriate. Despite initial published claims to the contrary, there is currently no good evidence for alternative splicing of TSP mRNAs or for heteropolymers of the trimeric TSPs. However, heteropentamers of TSP-4 and TSP-5 have been shown to exist in normal tendon and ligament (Hecht et al. 1998; Södersten et al. 2006).

\section{The identification of TSP-1 and TSP-2 as inhibitors of angiogenesis}

The involvement of TSP-1 in the regulation of angiogenesis was first recognized by Good et al. (1990). These workers purified a factor, secreted by baby hamster kidney (BHK) cells in culture, that inhibited the migration of bovine adrenal capillary EC, as well as corneal neo-vascularization that was stimulated by fibroblast growth factor 2 (FGF2). Expression of the factor was linked to that of a tumor suppressor gene in BHK cells (Rastinejad et al. 1989), and its characterization revealed an identity with a $\mathrm{C}$-terminal sequence in TSP-1. Good et al. also demonstrated that TSP-1 inhibited EC migration and proliferation in vitro. At about the same time, Taraboletti et al. (1990) showed that TSP-1 both

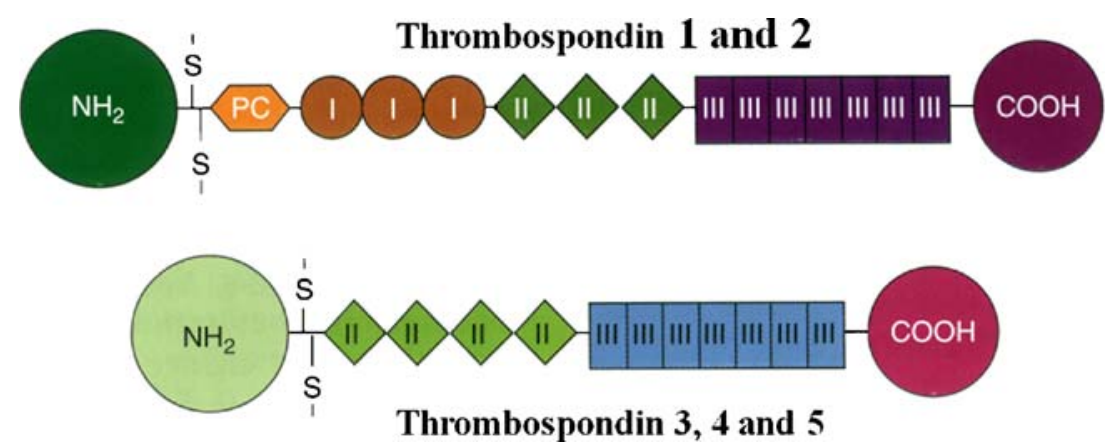

Fig. 1 A schematic representation of the structures of the individual chains in the thrombospondins. TSP-1 and TSP-2 are trimers and TSP-3, -4 , and -5 are pentamers. The sizes and amino acid sequences of the $\mathrm{NH}_{2}$-terminal domains vary considerably among the TSPs; in the case of TSP-5 this domain consists of only a few amino acids. The oligomerization domain, containing the interchain disulfide bonds, is followed by a procollagen homology domain (PC), also known as a von Willebrand type C repeat, and in the case of TSP-1 and TSP-2, by three type I (thrombospondin structural or properdin-like) repeats. All TSPs have type II (EGF-like) and type III (calcium binding) repeats, and a $\mathrm{COOH}$-terminal domain. Figure and legend are reproduced with permission from Bornstein, P. 'Matricellular Proteins' in Encyclopedia of Respiratory Medicine, G.J Laurent and S.D. Shapiro, Eds. Elsevier Limited, Oxford, UK; Volume 2, pp 175-183, 2006 
induced spreading of bovine aortic EC, and inhibited the mitogenic effects of serum and FGF2 on pulmonary capillary EC. These authors therefore also suggested that TSP-1 had anti-angiogenic properties. Subsequently, Tolsma et al. (1993) performed limited digestion of TSP-1 with chymotrypsin to produce fragments that inhibited rat corneal vascularization and invasion of polyvinyl sponges implanted in mice, as well as migration of EC in vitro. These peptides were derived primarily from the procollagen homology region and the second and third type I repeats in the $70 \mathrm{kD}$ central 'stalk' region of the protein (see Fig. 1). In subsequent studies, Iruela-Arispe et al. (1999) used the chicken chorioallantoic membrane (CAM) and EC proliferation assays to confirm the inhibition of angiogenesis by the second and third type I repeats. However, these investigators found no activity in the first repeat or in the procollagen homology region. Importantly, the capacity of a particular sequence to serve as a binding site for an angiogenic agent depended on the nature of the angiogenic stimulus. Thus, differences in receptor sequences in TSP-1 were observed for FGF2 and vascular endothelial growth factor (VEGF). These findings were supported by the earlier work of Taraboletti et al. (1997), who showed that FGF2 bound specifically to a $140 \mathrm{kDa}$ fragment of TSP-1. Many of these early studies have been ably reviewed by Chen et al. (2000). Documentation of the anti-angiogenic effects of TSP-2 has also been published (Volpert et al. 1995; Panetti et al. 1997; Noh et al. 2003; Simantov et al. 2005; see also the Section on the TSP-2-null mouse below).

Inhibition of angiogenesis is a consequence, in part, of reorganization of the actin cytoskeleton and disassembly of focal adhesions in EC by 'counteradhesive' proteins such as TSP-1 and -2, tenascin C, and SPARC (Sage and Bornstein 1991). For TSP-1, these effects are mediated by the $\mathrm{N}$-terminal domain of the cell-surface protein, calreticulin (Goicoechea et al. 2000, 2002). More recently, TSP-1 has been shown to inhibit not only cell-matrix interactions, but also cell-cell interactions in EC. This function is achieved by the phosphorylation of components of the cell-to-cell adherens junction or zonula adherens, and is mediated by the activation of two protein kinases, EGFR and ErbB2 (Liu et al. 2009).

\section{The phenotypes of TSP-1 and/or TSP-2-null mice provide important clues to the functions of these TSPs in the regulation of angiogenesis}

Disruption of all five TSP genes, individually, has been achieved in mice, but the phenotypes of TSP-1 and TSP-2null (knockout) mice are most relevant to this review. The phenotype of the TSP-1 knockout mouse as reported initially by Lawler et al. (1998) was limited to increased embryonic lethality, a mild spinal lordosis, and a propensity for pulmonary infections. While the infections are thought to reflect the lack of the chemotactic activity of TSP-1 for inflammatory cells in TSP-1-null mice, these findings did not reveal the important role that this protein is now known to play in the regulation of angiogenesis. However, subsequent studies have expanded our knowledge of this phenotype considerably. Thus Wang et al. (2003) reported that retinal vascular density was increased in TSP-1-null mice, compared with wild-type mice, and that TSP-1-null mice were less sensitive to hypoxia-mediated vessel obliteration and had a reduced rate of apoptosis of endothelial cells. Furthermore, Malek and Olfert (2009) have recently demonstrated an increased density of capillaries in cardiac and skeletal muscle in TSP-1-null mice, which was manifested as an increase in heart mass and in exercise capacity. These findings are consistent with our current knowledge of the function of TSP-1 as an important inhibitor of angiogenesis.

In contrast, the phenotype of the TSP-2 null mouse (Kyriakides et al. 1998) is marked by obvious abnormalities in the extracellular matrix (ECM) of skin, tendons and ligaments, and by increased vascularity in healing wounds and in the foreign body reaction (Kyriakides et al. 1999; Kyriakides and Bornstein 2003). As a consequence of this phenotype, wound healing is accelerated and the performance of implanted sensors and delivery devices is likely to be improved. However the importance of TSP-1 was revealed in the phenotype of double TSP-1/TSP-2 null mice (Agah et al. 2002). In these mice, wound healing is delayed, and the granulation tissue of healing wounds is not excessively vascularized. We can therefore conclude that the absence of TSP- 1 determines the course of wound healing in TSP-1/ TSP-2 null mice. Because TSP-1 is expressed earlier than TSP-2 in the course of wound healing, and the proinflammatory function of TSP-1 is necessary for normal wound healing, we propose that the complex program of wound repair, including the influx of blood vessels, is delayed and disrupted in double-null mice.

\section{The functions of TSP-1 and TSP-2 that regulate angiogenesis are determined by specific domains in these modular proteins}

The complex domain structures of TSP-1 and TSP-2 are illustrated in Figs. 1 and 2. As matricellular proteins, TSP-1 and TSP-2 function as regulators of multiple cell-cell and cell-ECM interactions and also bind directly to growth factors, cytokines, and proteases (Lawler 2000; Adams 2001; Bornstein 2001; Bornstein and Sage 2002; Lawler 2002). Figure 2 depicts some of the more important interactions with macromolecules and cell-surface receptors 


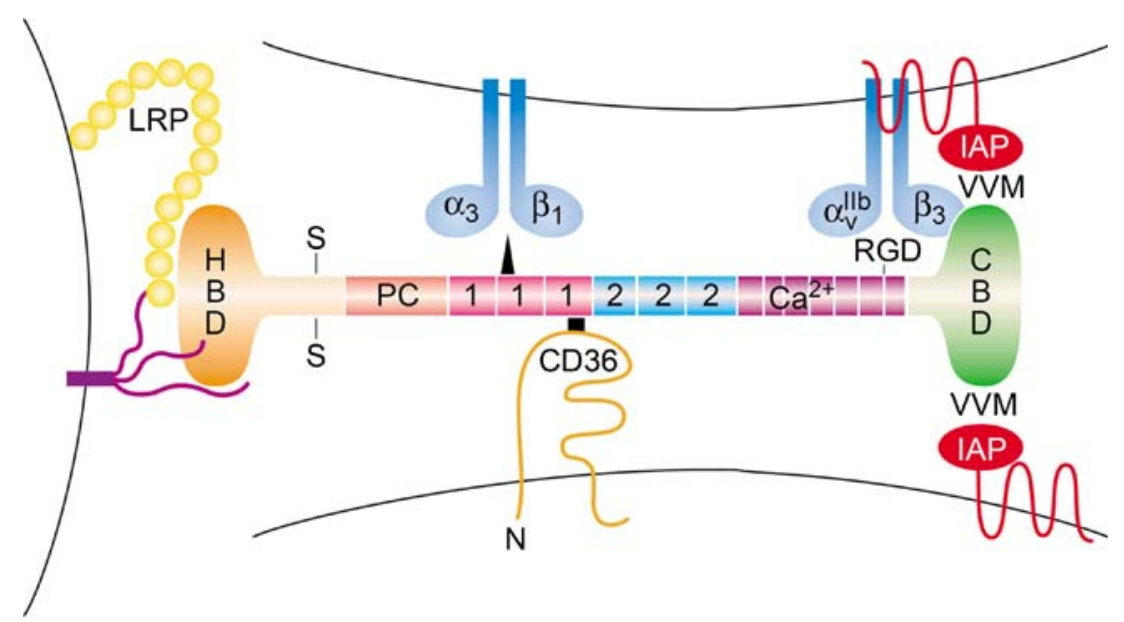

Fig. 2 A schematic representation of a generic TSP1 or TSP2 monomer together with the location of the binding sites for some of the major receptors with which the protein interacts, based on what was known in 2001. Changes resulting from more recent information are in [ ]. The structure of the chain is described in the legend to Fig. 1. The NH2-terminal heparin-binding domain (HBD) interacts with cell-surface heparan sulfate proteoglycans (purple), and the low density lipoprotein receptor-like protein,[LRP1], (yellow circles); the type 1 repeats bind to $\alpha 3 \beta 1$ integrin [as well as to other integrins] and CD36, [but more avidly with the HBD. Three additional integrins,

that mediate the regulation of angiogenesis by TSP-1 and TSP-2, and Table 1 provides a more complete list of these interactions and their functions. Much of this information has been gathered from the use of synthetic sequences of TSPs that encompass one or more of these domains, and of monoclonal antibodies that recognize specific domains in these proteins (Annis et al. 2006).

The $\mathrm{NH}_{2}$-terminal, heparin-binding domains of TSP-1 and TSP-2 bind heparan sulfate proteoglycans, which function as co-receptors for the low density lipoprotein receptor-related protein (LRP1). LRP1 is a scavenger receptor that functions to clear complexes of TSP-1, or TSP-2, with MMP2, MMP9, or VEGF from the pericellular environment of mesenchymal cells (Yang et al. 2001; Hahn-Dantona et al. 2001; Greenaway et al. 2007). The reduction in protease activity has an inhibitory effect on angiogenesis (Rodriguez-Manzaneque et al. 2001) and influences the structure of the ECM (Agah et al. 2005). As shown in Table 1, the $\mathrm{NH}_{2}$-terminal domains of TSP-1 and TSP-2 also interact with a number of integrins that have varied effects on the angiogenic response (see Table 1 for references). For example, the interaction with $\alpha 3 \beta 1$ integrin has been implicated in the angiogenic functions of TSP-1 (Chandrasekaran et al. 2000; see below)

The type I repeats mediate important interactions of TSP-1 and TSP-2 that include those with the small latent TGF $\beta 1$ complex (Schultz-Cherry et al. 1995; Crawford et al. 1998; Ribeiro et al. 1999) and CD36 (see below and $\alpha 4 \beta 1, \alpha 6 \beta 1$, and $\alpha 9 \beta 1$ also bind to the HBD]; the RGD sequence in the last $\mathrm{Ca}^{2+}$-binding type 3 repeat interacts with integrins $\alpha \mathrm{v} \beta 3$ and $\alpha 2 b \beta 3$. The $\mathrm{COOH}$-terminal cell-binding domain (CBD) contains two valine-valine-methionine (VVM) sequences that may interact with two integrin-associated protein (IAP/CD47) receptors on different cells, [but these interactions are now controversial]. More information on these interactions and on interactions with other receptors is provided in the text and in Table 1. The modified figure legend and figure are reproduced from Brown and Frazier (2001), with permission from Trends in Cell Biol

Table 1). TSP-1 has been shown to promote the mobilization of matrix-bound FGF-2 by interaction of FGF2 with its type I repeats, thus inhibiting the proliferation of EC (Margosio et al. 2003). It is important to note that the activating sequence, KRFK, in TSP-1 is replaced in TSP-2 by KRIR, which prevents the activation of latent TGF $\beta 1$ by TSP-2 (Schultz-Cherry et al. 1995). This difference between the two paralogs accounts for a significant fraction of the differences in their properties. Additional interactions of the type I repeats are summarized in Table 1. It is of interest that subdomains of the type I repeats have been identified that can discriminate, in their inhibitory capacity, between the stimulation of angiogenesis caused by FGF2 or VEGF, (Iruela-Arispe et al. 1999).

The type II and type III repeats were thought initially to be responsible for the adhesion of TSPs to EC, a property that was attributed chiefly to the RGD sequence that is present in the third type III repeat in both TSP-1 and TSP-2 (see Fig. 2). However, more recent studies (see Chandrasekaran et al. 2000) have not confirmed these findings and suggest that the interaction of $\beta-1$ integrins on the surface of endothelial cells with the N-terminal domain represents the major mechanism for their adhesion to TSP-1

The COOH-terminal domain of TSP-1 contains two sequences that share the adhesion motif, VVM, and are recognized by $\mathrm{CD} 47$, also known as integrin-associated protein (IAP); Kosfeld and Frazier 1993; Brown and Frazier 2001). However, only the second VVM sequence 
Table 1 Interactions and functions of specific domains in TSP-1 and TSP-2 in the regulation of angiogenesis*

\begin{tabular}{|c|c|c|c|}
\hline Domain & $\begin{array}{l}\text { Binding Receptors or } \\
\text { Molecules }\end{array}$ & Functions & References \\
\hline \multirow[t]{4}{*}{$\mathrm{NH}_{2}$-Terminal } & $\begin{array}{l}\text { HSPGs } \\
\text { LRP1 }\end{array}$ & $\begin{array}{l}\text { Adhesion of EC; co-receptor for LRP1 } \\
\text { Clearance of MMPs } 2 \text { and } 9\end{array}$ & $\begin{array}{l}\text { [Adams, 2001; Yang et al, 2001; } \\
\text { Lawler, 2000] [Yang et al, 2001; } \\
\text { Hahn-Dantona et al, 2001] } \\
\text { [Chandrasekaran et al, 2000] }\end{array}$ \\
\hline & $\begin{array}{l}\alpha 3 \beta 1 \\
\alpha 6 \beta 1\end{array}$ & $\begin{array}{l}\text { Stimulates angiogenesis; adhesion, } \\
\text { spreading and chemotaxis of cells }\end{array}$ & [Calzada et al, 2003] \\
\hline & $\alpha 9 \beta 1$ & $\begin{array}{l}\text { Adhesion of HUMVEC to immobilized } \\
\text { TSPs; chemotaxis of EC to soluble } \\
\text { TSPs Stimulates angiogenesis }\end{array}$ & \\
\hline & $\alpha 4 \beta 1$ & $\begin{array}{l}\text { Supports adhesion of venous EC and } \\
\text { mediates chemotaxis of microvascular EC }\end{array}$ & $\begin{array}{l}\text { [Staniszewska et al, 2007] } \\
\text { [Calzada et al, 2004a] }\end{array}$ \\
\hline \multirow[t]{2}{*}{ Type I Repeats } & $\begin{array}{l}\text { Small latent TGF } \beta 1 \\
\text { complex }\end{array}$ & Activation of latent $\operatorname{TGF} \beta 1^{* *}$ & $\begin{array}{l}\text { [Schultz-Cherry et al, 1995; } \\
\text { Ribeiro et al, 1999] }\end{array}$ \\
\hline & CD36 & $\begin{array}{l}\text { Induces apoptosis in EC in vitro and in } \\
\text { tumor-derived blood vessels in vivo }\end{array}$ & $\begin{array}{l}\text { [Jimenez et al, 2000; } \\
\text { Dawson et al, 1997] }\end{array}$ \\
\hline Types I and II Repeats & pan- $\beta 1$ integrins & & \\
\hline Type III Repeats & $\alpha \mathrm{v} \beta 3, \alpha \operatorname{IIb} \beta 3$ & $\begin{array}{l}\text { Modulate EC adhesion, inhibit EC migration } \\
\text { Adhesion of EC }\end{array}$ & $\begin{array}{l}\text { [Calzada et al, 2004b; Short et al, 2005] } \\
\text { [Adams, 2001; Lawler \& Hynes, 1989] }\end{array}$ \\
\hline $\mathrm{COOH}-\mathrm{Terminal}$ & CD47/IAP & Antagonizes NO-mediated vasodilation & [Isenberg et al, 2006] \\
\hline & $\alpha \mathrm{v} \beta 3, \alpha \operatorname{IIb} \beta 3$ & Adhesion and spreading of EC and platelets & [Brown and Frazier, 2001] \\
\hline
\end{tabular}

HSPGs heparan sulfate proteoglycans; HUMVEC human umbilical vein endothelial cells; $E C$ endothelial cells

* Modified and reproduced, with permission, from Angiogenesis: An Integrative Approach from Science to Medicine, Paul Bornstein, Chapter 13. Edited by William D. Figg and Judah Folkman. Springer Science and Business Media, LLC, 2008

** Function not shared with TSP2

is exposed in the crystal structure of TSP-1. CD47 in TSP-1 associates with a number of integrins to promote the spreading of platelets, EC, and other cells. Recently, CD47 has been shown to be involved in the inhibition of vascular cell responses to nitric oxide (NO) by TSP-1 (Isenberg et al. 2006; see section on nitric oxide). Since TSP-2 lacks the second VVM sequence present in TSP-1, the functions resulting from the interaction of TSP-1with CD-47 may not be shared by TSP-2.

\section{TSP1 and TSP2 inhibit angiogenesis by a pro-apoptotic mechanism that is mediated by their interaction with CD36}

Guo et al. (1997) were the first investigators to document that TSP-1, and peptides derived from its type I repeats, cause apoptosis in cultured EC. A major source of antiangiogenic peptides is the $36 \mathrm{kDa}$ fragments generated by cleavage of either TSP-1 or TSP-2 by the ADAMTS1 proteinase (Lee et al. 2006). Apoptosis, assessed by morphological changes and DNA fragmentation, did not depend on activation by TGF- $\beta 1$, and was reduced when cells were confluent or were plated on fibronectin. At about the same time, Dawson et al. (1997) showed that the inhibitory effect of TSP-1 on angiogenesis was dependent on the level of expression of the transmembrane receptor, CD36, in human umbilical vein endothelial cells. An $88 \mathrm{kDa}$ glycoprotein, CD36 was known to be an adhesion receptor for TSP-1 (Asch et al. 1993) and serves as a scavenger receptor for anionic phospholipids, apoptotic cells, and rod outer segments in the retina (see Dawson et al. 1997 for references). The clearest evidence that TSP-2 also interacted with CD36 to inhibit angiogenesis has been provided by Simantov et al. (2005). These authors also showed that histidine-rich glycoprotein (HRGP), interacted with TSP-1 and -2 , thus acting as a decoy receptor and an inhibitor of the anti-angiogenic functions of the TSPs. It is of interest that HRGP contains a so-called CLESH domain, a region homologous to the binding site for TSPs in CD36. Some of the earlier history of the pro-apoptotic effects of TSP-1 has been described in previously published reviews (Lawler 2002; Armstrong and Bornstein 2003). Comprehensive reviews of the molecular mechanisms involved in the pro-apoptotic functions of TSP-1 and TSP-2, including the role of CD36 in these processes, have recently been published (Silverstein and Febbraio 2007; Mirochnik et al. 2008)

The signaling pathway that leads from engagement of CD36 by TSP-1 or TSP-2 on one cell to the activation of 
caspases, both in that cell and in adjacent cells, was elucidated by Jimenez et al. (2000). An abbreviated scheme of this pathway is presented in Fig. 3. The binding and activation of $\mathrm{CD} 36$, a process inhibited competitively by histidine-rich glycoprotein, leads to its interaction with p5 $59^{\text {fyn }}$, a member of the Src-family of tyrosine kinases. In a subsequent step, p59 fyn activates p38MAPK and Jun $\mathrm{N}$-terminal kinase (JNK); this step requires the action of caspases 3 and 8, members of the group II caspaces that are associated with apoptosis. An apoptotic cascade is subsequently triggered by the interaction of Fas ligand (FasL) on one cell with a Fas receptor on another (Fig. 3). Recently TSP-1 has been shown to induce apoptosis in brain microvascular EC by a different pathway that requires tumor necrosis factor (TNF) receptor 1 and caspases 3 and 8 (Rege et al. 2009). This mechanism entails the induction of TNF $\alpha$ mRNA and protein. Although both TSP-1 and TSP-2 have been shown to be capable of causing apoptosis in cells in culture, and in tumor cells in vivo, the ability of these proteins to function

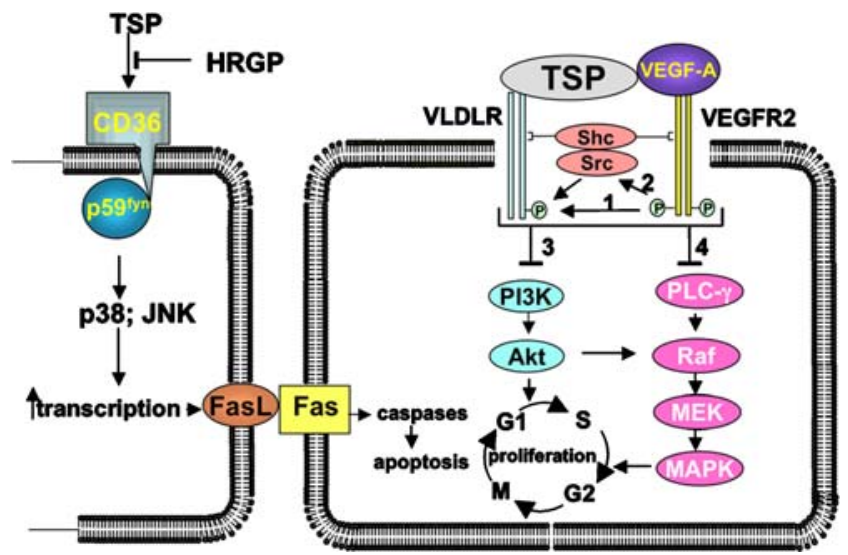

Fig. 3 A scheme that describes the apoptotic (left) and homeostatic (right) functions of the TSPs. Left: the mechanism, described by Jimenez et al. (2000), and extended by Rege et al. (2009), for the apoptotic function of TSP-1 or -2 . Activation of CD36 also leads directly to an increase in transcription of caspaces and the TNF-R. Right: the coordinate and integrated interaction of TSP-1 or -2 with theVLDLR and VEGF-bound VEGFR, together with the activation of Src and the adapter protein, Shc, leads to an inhibition of the PI3K and MAPK pathways, and consequently, of cell cycle progression in EC. The bridging of the VLDLR and the VEGFA-ligated VEGFR by TSP-1 or -2 is conjectural. The mechanisms encompassed by the bracket are based on analogous pathways recently described for the activated PDGF receptor-beta and LRP1 (see Newton et al. 2005). As indicated by arrow 1 , the activated VEGFR phosphorylates an NPXY sequence on the VLDLR. Arrow 2 indicates that the kinase domain of the VEGFR also activates Src, which phosphorylates the VLDLR, and Shc, which bridges the two receptors by virtue of its two docking domains, $\mathrm{SH} 2$ and PTB. These reactions lead, by mechanisms that have not yet been defined, to the inhibition of the P13K/Akt (3) and MAPK (4) pathways, and the consequent inhibition of cell cycle progression. The modified and updated figure legend and the figure are reproduced from Oganesian et al. Mol Biol Cell 19: 1563, 2008 with permission from The American Society for Cell Biology as pro-apoptotic agents in normal cells in vivo remains to be confirmed.

\section{TSP-1 and TSP-2 also serve a homeostatic function, mediated by the VLDL receptor, in the regulation of angiogenesis}

The requirement for a homeostatic function for TSP-1 and TSP-2 in a normal adult animal was suggested by the following considerations. 1) The rate of replication of aortic EC in healthy adult rats ranges from 2 to 10 months, depending on their anatomical location, and longer life spans might be expected in humans (see references in Oganesian et al. 2008 for this and subsequent points). 2) This quiescence exists despite the fact that plasma contains sufficient VEGF to stimulate EC growth. 3) In the event of trauma, it would seem preferable for ECs in the periphery of a wound to become quiescent rather than to undergo apoptosis in response to TSP-1 released from platelets, because the exposure of additional sub-endothelial matrix could lead to more extensive and undesirable thrombosis.

Initial work by Armstrong et al. (2002) indicated that both TSP-1 and TSP-2 can inhibit the proliferation of human microvascular EC (HMVEC) in the absence of cell death, and that the mechanisms responsible for inhibition of cell cycle progression differed from those leading to apoptosis. More recently, Oganesian et al. (2008) have established that the homeostatic function of both TSP-1 and TSP-2 is mediated by the VLDL receptor (VLDLR), a member of the LRP receptor family. Additional information regarding the VLDL receptor can be found in Oganesian et al. (2008). As shown in Fig. 3, the coordinated interaction of TSP-1 or -2 bound to the VLDLR, and VEGF bound to the VEGFR, leads to an inhibition of the P13K and MAPK pathways, and consequently to the inhibition of cell cycle progression in EC. This scheme is analogous to the coreceptor function of the platelet-derived growth factor receptor and LRP1 (Newton et al. 2005).

Recently, the work of Blake et al. (2008) has confirmed the interaction between the VLDLR and TSP-1. These workers showed that this interaction induces phosphorylation of Dab1 in the subventricular zone of the brain, and that the consequent signaling during the postnatal migration of neuronal precursors from the subventricular zone to the olfactory bulb stabilizes subventricular neuronal chains. Jiang et al (2009) have also reported signaling from the VLDLR in retinal vascular EC. Although the role of TSPs was not examined in this study, the fact that angiogenesis was increased in VLDLR-null mice suggests that TSPs could inhibit angiogenesis in the retinas of wild-type mice. 
TSP-1 inhibits signaling by nitric oxide (NO): consequences for vascularity and angiogenesis

$\mathrm{NO}$ is a bioactive gas that is produced by conversion of L-arginine to L-citruline, a reaction catalyzed by three NO synthases. NO relaxes vascular smooth muscle cells and thus increases blood vessel diameter and blood flow (Isenberg et al. 2009a). However, in the context of the regulation of angiogenesis by TSPs, NO also markedly increases the inhibitory potency of TSP-1 (see reviews by Isenberg et al. 2008a, 2009a, b, for details of the function of NO). TSP-1, by binding to CD47, also known as IAP, reduces the dilatation of blood vessels by NO. Thus, Isenberg et al. (2008b) have shown that gene silencing of CD47, by use of CD47antisense morpholino oligonucleotides, or antibody blockade of TSP-1, increases the patency of blood vessels and can therefore increase the survival of ischemic tissues. Similar results were achieved in mice that lacked CD47 (Isenberg et al. 2007a). Since TSP-1 also limits vascular smooth muscle cell relaxation (Isenberg et al. 2007b), its expression can therefore contribute to tissue ischemia by different mechanisms.

Recently, the interactions of the 'signature domains' of TSPs- $1,-2$ and -4 (comprised of the types III repeats and the C-terminal domain) with $\mathrm{CD} 47$, and their capacity to modulate cGMP signaling, were compared (Isenberg et al. 2009a, b). In these assays, TSP-1was found to be more effective than either TSP-2 or TSP-4 in the inhibition of NO-stimulated cGMP synthesis in vascular smooth muscle cells. Based on these and other experiments, Isenberg et al. concluded that TSP-1 is the dominant regulator of CD47mediated NO/cGMP signaling, and that its role in limiting responses to acute ischemic injuries is not shared by TSP-2.

\section{TSP-1 and TSP-2 also subserve an angiogenic function}

Despite the extensive experimental data that point to an anti-angiogenic function for TSP-1 and -2 , evidence has gradually accumulated that, paradoxically, also supports an angiogenic function for these proteins. In 1994, Nicosia and Tuszynski described experiments in which rat aortic rings were implanted in collagen and fibrin matrices containing TSP-1. In these experiments they observed a concentrationdependent outgrowth of microvessels from these aortic explants and concluded that TSP-1 stimulated the outgrowth of myofibroblasts from the aortic rings, and thereby promoted the formation of microvessels. However, the mechanisms that led to the increase in proliferation of the EC, and that would be required for blood vessel formation in these experiments, were not characterized. Subsequently, Qian et al. (1997) showed that the capacity of bovine aortic EC to invade and form micro-vessel-like tubes in collagen gels was increased at low concentrations of exogenous TSP-1, but was inhibited at higher concentrations. This biphasic effect was correlated with the stimulation of matrix metalloproteinase-9 (MMP-9) activity by TSP-1. Thus Qian et al. proposed that TSP-1, via activated MMP-9, was responsible for gel invasion and tube formation by EC, because these functions were inhibited by antibodies against either protein. However, these results are subject to the reservation that bovine aortic EC, rather than microvascular EC, were used in the experiments. In support of an angiogenic function for TSP-1, Taraboletti et al. (2000) used thrombin to digest human platelet TSP-1 into $\mathrm{NH}_{2}$ terminal heparin-binding fragments of $25 \mathrm{kDa}$ and $\mathrm{COOH}-$ terminal fragments of $140 \mathrm{kDa}$. In a rabbit corneal assay, both intact TSP- 1 and the $25 \mathrm{kDa}$ fragment promoted the angiogenesis induced by FGF2, whereas the $140 \mathrm{kDa}$ fragment did not induce angiogenesis and inhibited the angiogenic response to FGF2. The authors concluded, on the basis of these and other experiments, that intact TSP-1 could be the source of smaller peptides that functioned in a manner opposite to that of the intact protein.

Additional support for an angiogenic function of TSP-1 has been contributed by Roberts and coworkers. Chandrasekaran et al. (2000) showed that the interaction of $\alpha 3 \beta 1$ integrin with immobilized TSP-1 stimulated angiogenesis. This interaction was inhibited by a soluble peptide from TSP-1 and by the interaction of the $\alpha 3 \beta 1$ integrin with VE cadherin, but was stimulated by the interaction of the $\alpha 3 \beta 1$ integrin with CD98. The outcome of these interactions is further complicated by whether or not the peptide is part of a larger fragment of TSP-1. More recently, Staniszewska et al. (2007) showed that TSP-1 also interacts with $\alpha 9 \beta 1$ integrin via its $\mathrm{N}$-terminal domain. $\alpha 9 \beta 1$ is expressed on microvascular EC in several organs and its interaction with sequences from the N-terminal domain of TSP-1 induced neovacularization in quail chorioallantoic membranes and in a matrigel plug formation assay in mice. $\alpha 4 \beta 1$ and $\alpha 6 \beta 1$ have also been shown to interact with TSP-1 (Calzada et al. 2004a, b), but the evidence for an angiogenic function for these interactions is incomplete.

\section{The regulation of angiogenesis by TSP-1 and TSP-2 in tumors}

There is ample evidence for inhibition of both tumorigenic (Hawighorst et al. 2001; see Kazerounian et al. 2008 for a review) and non-tumorigenic (Cursiefen et al. 2004) angiogenesis by endogenous TSP-1 and TSP-2. Because the effects of TSP-1 and TSP-2 on the proliferation of ECs are predominantly inhibitory, there has been considerable interest in their potential, and in that of peptides from the two proteins, as anti-tumor agents. However, in keeping 
with the evidence that TSP-1 can also stimulate angiogenesis, both inhibitory and stimulatory effects have been reported (see Roberts 1996 for a review of the early literature). Furthermore, there are several different sources of endogenous TSP-1 in tumors, including the malignant cells themselves and the host-derived vasculature and stroma, and each of these cellular compartments is subject to different and complex regulation. The outcome of the addition of exogenous TSP-1 can therefore be difficult to predict.

Nevertheless, recent advances in molecular and cell biology have suggested novel means by which the manipulation of TSP levels can be used in the regulation of angiogenesis. Thus studies have established that prosaposin, a precursor form of the lipid hydrolase activators, saposin A-D, stimulates the expression of TSP-1 in both tumors and in normal tissues in a p53-dependent manner (Kang et al. 2009). These studies confirm earlier findings by Dameron et al. (1994), that established a role for p53 in the regulation of expression of TSP-1. Furthermore, there is now evidence that the expression of microRNAs can be used to regulate angiogenesis (Kuehbacher et al. 2007; Dews et al. 2006) Thus, it is plausible that manipulation of microRNA levels could be used eventually to selectively increase TSP levels in tumors and surrounding tissues.

In 1997, Castle et al. showed that transfection of cDNA for intact TSP-1, or for its N-terminal domain, into $s r c-\mathrm{NIH}$ 3 T3 cells suppressed angiogenesis and tumor formation when the transfected cells were injected into nude mice. Subsequently, Tokunaga et al. (1999) quantified expression of TSP-1 and TSP-2 by RT-PCR in patients with colon cancer. More than half of the patients' cancers expressed TSP-2, and these patients exhibited a significantly reduced incidence of hepatic metastases and tumor vascularity in comparison with patients whose tumors were negative for TSP-2. A similar correlation with expression of TSP-1 was not found. Along these lines, de Fraipont et al. (2001) conducted a survey of 18 published papers in which the level of expression of TSP-1 or -2 was correlated with clinical status and outcome. Despite the variables in these studies, for example studies that used biochemical methods to quantify TSPs did not distinguish between stromal versus tumoral sources of the TSPs, the authors concluded that, for most of the tumors, there was an inverse correlation between the level of TSP in the tumor and the degree of its malignancy. However, in keeping with evidence for an angiogenic function for TSP-1, Tuszynski and Nicosia (1996) have also summarized the evidence that TSP-1 can actually promote tumor progression. Additional information concerning the effects of TSP-1 and TSP-2 in tumor progression is provided in a review by Lawler and Detmar (2004).

\section{The potential for use of TSP-1-derived peptides in clinical anti-angiogenic therapy}

There are a number of ways in which the properties of TSP-1 and -2 could be used to inhibit the vascularity and/or growth and metastasis of tumors. For example, TSP-1 binds VEGF directly, and the complex can be endocytosed by the scavenger receptor, LRP1 (Greenaway et al. 2007). This clearance function is analogous to that by which TSPs reduce the levels of MMP2 (Yang et al. 2001) and MMP9 (Hahn-Dantona et al. 2001) in the pericellular environment. Similarly, other anti-angiogenic functions of TSP-1 and -2, described in this review, could be exploited. However, approaches that require administration of intact TSP are clearly not feasible in a clinical setting, and neither are cellbased therapies or therapies that depend on the use of viruses as delivery agents (Hahn et al. 2004; see review by Mirochnik et al. 2008, for a more complete review of the limitations of therapy with TSP-1).

On the other hand, peptides that mimic sequences in the type I repeats of TSP-1 show considerable promise as antitumor agents. Haviv et al. (2005) synthesized a series of peptides based on a sequence in the second type I repeat of human TSP-1. Selected peptides, modified to increase their stability in vivo, were then tested for their anti-angiogenic properties by several criteria: inhibition of tube formation by human microvascular EC; induction of apoptosis; inhibition of EC migration; and inhibition of capillary sprout formation. Two of the peptides, ABT-526 and ABT510 , which showed the most promise, were then tested for their effectiveness as inhibitors of angiogenesis and tumor progression in animals. ABT-526 was found to be effective in the inhibition of neovascularization in a rat cornea model, and ABT-510 reduced the growth of a syngeneic Lewis lung carcinoma in mice (Haviv et al. 2005).

The type I TSP repeats are also present in a number of related proteins other than the TSPs, such as pigment epithelium-derived factor (PEDF), WISP-1, and brain angiogenesis inhibitor-1(BAI-1). PEDF has been shown to be a potent inhibitor of angiogenesis in the mammalian eye (Dawson et al. 1999). WISP-1 contains an 18 amino acid sequence, termed wispostatin-1, which is very similar to the Mal II and Mal III sequences in the type I repeats of TSP-1. Cano et al. (2009) found that wispostatin-1 inhibited the migration and proliferation of human retinal EC, abolished FGF-induced retinal neo-vascularization in a corneal micropocket assay, and inhibited laser-induced choroidal neovascularization in mice. BAI-1, which contains five TSP type I repeats, can be cleaved at a conserved proteolytic cleavage site to release a soluble anti-angiogenic fragment termed vasculostatin, which contains these repeats (Kaur et al. 2005). Vasculostatin suppresses the growth of malignant gliomas in rats and inhibits the migration of human dermal 
microvascular EC, but not that of human umbilical vein EC. These effects are dependent on the presence of CD36 on EC (Kaur et al. 2009). Most recently, Ren et al. (2009) have evaluated the ability of a 'double hit,' consisting of tumor necrosis factor-related apoptosis-inducing ligand (TRAIL) and a TRAIL receptor 2 agonist antibody (Lexatumumab), which is directed to the type I repeats in TSP-1, to inhibit the progression of human colon cancer in nude mice and to induce apoptosis in human dermal microvascular EC. Favorable results were observed in both assays.

Perhaps the most encouraging studies that set the stage for the use of TSP peptide mimetics in the treatment of tumors in patients, involve the TSP-1derived peptides, ABT-526 and ABT-510, developed by Haviv et al. (2005). Hoekstra et al. (2006), in a Phase I study, reported that the inclusion of ABT-510 in a course of therapy with 5-fluorouracil and leucovorin showed no ill effects in patients with solid tumors. Two studies in dogs are also encouraging. ABT-510 and ABT-526 were used to treat malignant tumors in 242 pet dogs. No dose-limiting toxicity was observed in any of the animals, and 42 of the dogs showed a greater than $50 \%$ reduction in tumor size (Rusk et al. 2006a). In a second study of pet dogs with relapsed non-Hodgkin's lymphoma, ABT-526 was added to chemotherapy with lomusine. Whereas no difference was observed in the rate of response, there was a significant increase in its duration, with no attendant toxicity (Rusk et al. 2006b). In a different animal model, Greenaway et al. (2009) showed that ABT-510 was effective in the induction of apoptosis of syngeneic mouse epithelial cancer cells, introduced into the bursa of C57BL/6 mice. Finally, in a recent phase II study, Baker et al. (2008) treated patients with advanced soft tissue sarcoma with ABT-510. Although a favorable safety profile was observed, and the rate of disease control and overall survival were encouraging, the authors concluded that compelling evidence for the efficacy of ABT-510 as a single agent in this disease had not been achieved.

Additional trials with these two peptide mimetics are clearly necessary, and are likely to be performed. Hopefully, a reduction in the morbidity of some human cancers that results from a combinational therapy, including TSP derivatives, will be forthcoming.

Acknowledgments I thank Helene Sage for a careful reading of this manuscript and for helpful suggestions.

Open Access This article is distributed under the terms of the Creative Commons Attribution Noncommercial License which permits any noncommercial use, distribution, and reproduction in any medium, provided the original author(s) and source are credited.

\section{References}

Adams JC (2001) Thrombospondins: multifunctional regulators of cell interactions. Annu Rev Cell Dev Biol 17:25-51

Agah A, Kyriakides TR, Lawler J, Bornstein P (2002) The lack of thrombospondin-1 (TSP1) dictates the course of wound healing in double-TSP1/TSP2-null mice. Am J Pathol 161:831-839

Agah A, Kyriakides TR, Bornstein P (2005) Proteolysis of cell-surface transglutaminase by matrix metalloproteinase- 2 contributes to the adhesive defect and matrix abnormalities in thrombospondin-2-null fibroblasts and mice. Am J Path 167:81-88

Annis DS, Murphy-Ullrich JE, Mosher DF (2006) Function-blocking anti-hrombospondin-1 monoclonal antibodies. J Thromb Haemost 4:459-468

Armstrong LC, Björkblom B, Hankenson KD, Siadek AW, Stiles CE, Bornstein P (2002) Thrombospondin 2 inhibits microvascular endothelial cell proliferation by a caspase-independent mechanism. Mol Biol Cell 13:1893-1905

Armstrong LC, Bornstein P (2003) Thrombospondins 1 and 2 function as inhibitors of angiogenesis. Matrix Biol 22:63-71

Asch AS, Liu I, Briccetti EM, Barnwell F, Kwakye-Berko F, Dokun A, Goldberger J, Pernambuco M (1993) Analysis of CD 36 binding domains: ligand specificity controlled by dephosphorylation of an ectodomain. Science 262:1436-1440

Baker LH, Rowinsky RK, Mendelson D, Humerickhouse RA, Knight RA, Qian J, Carr RA, Gordon GB, Demetri GD (2008) Randomized phase II study of the thrombospondin-1 mimetic angiogenesis inhibitor ABT-510 in patients with advanced soft tissue sarcoma. J Clin Oncol 26:583-588

Baenziger NL, Brodie GN, Majerus PW (1971) A thrombin-sensitive protein of human platelet membranes. Proc Nat Acad Sci USA 68:240-243

Baenziger NL, Brodie GN, Majerus PW (1972) Isolation and properties of a thrombin-sensitive protein of human platelets. J Biol Chem 247:2723-2731

Blake SM, Strasser V, Andrate N, Duit S, Hofbauer R, Schneider WJ, Nimpf J (2008) Thrombospondin-1binds to ApoER2 and VLDL receptor and functions in postneural migration. EMBO $\mathrm{J}$ 27:3069-3080

Bornstein P, O'Rourke KO, Wikstrom K, Wolf W, Katz R, Li P, Dixit VM (1991) A second expressed thrombospondin gene (Thbs2) exists in the murine genome. J Biol Chem 266:12821-12824

Bornstein P (2001) Thrombospondins as matricellular modulators of cell function. J Clin Invest 107:929-934

Bornstein P, Sage EH (2002) Matricellular proteins: extracellular modulators of cell function. Current Opin Cell Biol 14:608-616

Brown EJ, Frazier WA (2001) Integrin-associated protein (CD47) and its ligands. Trends Cell Biol 11:130-135

Calzada MJ, Sipes JM, Krutzsch HC, Yurchenko PA, Annis DS, Mosher DF, Roberts DD (2003) Recognition of the N-terminal modules of thrombospondin-1and thrombospondin- 2 by $\alpha 6 \beta 1$ integrin. J Biol Chem 278:40679-40687

Calzada MJ, Zhou L, Sipes JM, Zang J, Krutzsch HC, Iruela-Arispe ML, Annis DS, Mosher DF, Roberts DD (2004a) $\alpha_{4} \beta_{1}$ integrin mediates selective endothelial cell responses to thrombospondins 1 and 2 in vitro and modulates angiogenesis in vivo. Circ Res 94:462-470

Calzada MJ, Annis DS, Zeng B, Marcinkiewicz C, Banas C, Lawler J, Mosher DF, Roberts DD (2004b) Identification of novel $\beta 1$ integrin binding sites in the type 1 and type 2 repeats of thrombospondin-1. J Biol Chem 279:41734-41743

Cano M, Karagiannis ED, Soliman M, Bakir B, Zhuang W, Popel AS, Gehlbach PL (2009) A peptide derived from type I thrombospondin repeat-containing protein Wisp-1 inhibits corneal and choroidal neovascularization. Invest Ophthalmol Vis Sci 50:3840-3845 
Castle VP, Dixit VM, Polverini PJ (1997) Thrombospondin-1 suppresses Tumorigenesis and angiogenesis in serum- and anchorage-independent NIH 3 T3 cells. Lab Invest 77:51-61

Chandrasekaran L, He C-Z, Al-Barazi H, Krutzsch HC, Iruela-Arispe ML, Roberts DD (2000) Cell contact-dependent activation of $\alpha 3 \beta 1$ integrin modulates endothelial cell responses to thrombospondin-1. Mol Biol Cell 11:2885-2890

Chen H, Herndon ME, Lawler J (2000) The cell biology of thrombospondin-1. Matrix Biol 19:597-614

Crawford SE, Stellmach V, Murphy-Ullrich JE, Ribeiro SM, Lawler J, Hynes RO, Boivin GP, Bouck N (1998) Thrombospondin-1 is a major activator of TGF $\beta 1$ in vivo. Cell 93:1159-1170

Cursiefen C, Masli S, Ng TF, Dana R, Bornstein P, Lawler J, Streilein W (2004) Roles of thrombospondin-1 and -2 in regulating corneal and iris angiogenesis. Invest Ophthalmol Vis Sci 45:1117-1124

Dameron KM, Volpert OV, Tainsky MA, Bouck N (1994) Control of angiogenesis in fibroblasts by p53 regulation of thrombospondin 1. Science $265: 1582-1584$

Dawson DW, Pearce SF, Zhong R, Silverstein RL, Frazier WA, Bouck NP (1997) CD36 mediates the in vitro inhibitory effects of thrombospondin-1 on endothelial cells. J Cell Biol 138:707-717

Dawson DW, Volpert OV, Gillis P, Crawford SE, Xu HJ, Benedict W, Bouck NP (1999) Pigment epithelium-derived factor: a potent inhibitor of angiogenesis. Science 285:245-248

de Fraipont F, Nicholson AC, Feige J-J, Van Meir EG (2001) Thrombospondins and tumor angiogenesis. Trends Mol Med 7:401-407

Dews M, Homayouni A, Yu D, Murphy D, Sevignani C, Wentzel E, Furth EE, Lee WM, Enders GH, Mendell T, Thomas-Tikhonenko $\mathrm{T}$ (2006) Augmentation of tumor angiogenesis by a Mycactivated microRNA cluster. Nat Genet 38:1060-1065

Goicoechea S, Orr AW, Pallero MA, Eggleton P, Murphy-Ullrich JE (2000) Thrombospondin mediates focal disadhesion through interactions with cell surfave calreticulin. J Biol Chem 275:36358-36368

Goicoechea S, Pallero MA, Eggleton P, Michalak M, Murphy-Ullrich JE (2002) The antiadhesive activity of thrombospondin is mediated by the N-terminal domain of cell surface calreticulin. J Biol Chem 277:37219-37228

Good DJ, Polverini PJ, Rastinejad F, Le Beau MM, Lemons RS, Frazier WA, Bouck NP (1990) A tumor suppressor-dependent inhibitor of angiogenesis is immunologically and functionally indistinguishable from a fragment of thrombospondin. Proc Natl Acad Sci USA 87:6624-6628

Greenaway J, Moorehead RP, Bornstein P, Lawler J, LaMarre J, Petrik J (2007) Thrombospondin-1 inhibits VEGF levels in the ovary directly by binding and internalization via the low density lipoprotein receptor-related protein-1 (LRP-1). J Cell Physiol 210:807-818

Greenaway J, Henkin J, Lawler J, Moorehead R, Petrik J (2009) ABT510 induces tumor cell apoptosis and inhibits ovarian tumor growth in an orthotopic, syngeneic model of epithelial ovarian cancer. Mol Cancer Ther 8:64-74

Guo N-H, Krutzsch HC, Inman JK, Roberts DD (1997) Thrombospondin 1 and type I repeat peptides of thrombospondin 1 specifically induce apoptosis of endothelial cells. Cancer Res 57:1735-1742

Hahn W, Ho S-H, Jeong J-G, Hahn E-Y, Kim S, Yu SS, Kim J-M (2004) Viral vector-mediated transduction of a modified thrombospondin-2 cDNA inhibits tumor growth and angiogenesis. Gene Ther 11:739-745

Hahn-Dantona E, Ruiz JF, Bornstein P, Strickland DK (2001) The low density lipoprotein receptor-related protein modulates levels of matrix metalloproteinase 9 (MMP-9) by mediating its cellular catabolism. J Biol Chem 276:15498-15503

Haviv F, Bradley MF, Kalvin DM, Schneider AJ, Davidson DJ, Majest SM, McKay LM, Haskell CJ, Bell RL, Nuyen B, Marsh KC, Surber BW, Uchic JT, Ferrero J, Wang Y-C, Leal J, Record
RD, Hodde J, Badylak SF, Lesniewski RP, Henkin J (2005) Thrombospondin-1 mimetic peptide inhibitors of angiogenesis and tumor growth: design, synthesis, and optimization of pharmacokinetics and biological activities. J Med Chem 48:2838-2846

Hawighorst T, Velasco P, Streit M, Hong Y-K, Kyriakides TR, Brown LF, Bornstein P, Detmar M (2001) Thrombospondin-2 plays a protective role in multistep carcinogenesis: a novel host anti-tumor defense mechanism. EMBO J 20:2631-2640

Hecht JT, Deere M, Putnam E, Cole W, Vertel B, Chen H, Lawler J (1998) Characterization of cartilage oligomeric matrix protein (COMP) in human normal and pseudoachondroplasia musculoskeletal tissues. Matrix Biol 17:269-278

Hedblom E, Antonsson P, Hjerpe A, Aeschlimann D, Paulsson M, RosaPimentel E, Sommarin Y, Wendel $\mathrm{M}$, Oldberg A, Heinegård D (1992) Cartilage Matrix proteins. An acidic oligomeric protein (COMP) detected only in cartilage. J Biol Chem 267:6132-6136

Hoekstra R, de Vos FY, Eskens FA, deVries EG, Uges DR, Knight B, Carr RA, Humeriek R, Verweij J, Gietema JA (2006) Phase I study of the thrombospondin-1-mimetic angiogenesis inhibitor ABT-510 with 5- fluorouracil and leucovorin: a safe combination. Eur J Cancer 42:467-472

Iruela-Arispe ML, Lombardo M, Krutzsh C, Lawler J, Roberts DD (1999) Inhibition of angiogenesis by thrombospondin-1 is mediated by two independent regions within the type I repeats. Circulation 100:1423-1431

Isenberg JS, Ridnour LA, Dimitry J, Frazier WA, Wink DA, Roberts DD (2006) CD47 is necessary for inhibition of nitric oxidestimulatedvascular cell responses by thrombospondin-1. J Biol Chem 81:26069-26080

Isenberg JS, Romeo MJ, Abu-Asab M, Tsokos M, Oldenborg A, Pappan L, Wink DA, Frazier WA, Roberts DD (2007a) Increasing survival of ischemic tissue by targeting CD47. Circ Res 100:712-720

Isenberg JS, Hyodo F, Matsumoto K-I, Romeo MJ, Abu-Asab M, Tsokos M, Kuppusamy P, Wink DA, Krishna MC, Roberts DD (2007b) Thrombospondin-1 limits ischemic tissue survival by inhibiting nitric oxide-mediated vascular smooth muscle relaxation. Blood 109:1945-1952

Isenberg JS, Frazier WA, Roberts DD (2008a) Thrombospondin-1: a physiological regulator of nitric oxide signaling. Cell Mol Life Sci 65:728-742

Isenberg JS, Romeo MJ, Maxhimer JB, Smedley J, Frazier WA, Roberts DD (2008b) Gene silencing of CD47 and antibody ligation of thrombospondin-1 enhance tissue survival in a porcine model. Implications for human disease. Ann Surg 247:860-868

Isenberg JS, Annis DS, Pendrak ML, Ptaszynska M, Frazier WA, Mosher DF, Roberts DD (2009a) Differential interactions of thrombospondins- $1,-2$, and -4 with CD47 and effects on cGMP signaling and ischemic responses. J Biol Chem 284:1116-1125

Isenberg JS, Martin-Manso G, Maxheimer JB, Roberts DD (2009b) Regulation of nitric oxide signaling by thrombospondin 1: implications for antiangiogenic therapies. Nature Reviews/Cancer 9:182-194

Jaffe EA, Ruggiero JT, Leung LK, Doyle MJ, McKeon-Longo PJ, Mosher DF (1983) Cultured human fibroblasts synthesize and secrete thrombospondin and incorporate it into extracellular matrix. Proc Natl Acad Sci USA 80:998-1002

Jiang A, Hu W, Meng H, Gao H, Qiao X (2009) Loss of VLDL receptor activates vascular endothelial cells and promotes angiogenesis. Invest Ophthalmol Vis Sci 50:844-850

Jimenez B, Volpert OV, Crawford SE, Febbraio M, Silverstein RL, Bouck N (2000) Signals leading to apoptosis-dependent inhibition of neovascularization by thrombospondin-1. Nature Med $6: 41-48$

Kang S-y, Hakverson OJ, Gravadal K, Battacharya N, Lee JM, Liu NW, Johnston BT, Johnston AB, Haukaas SA, Amodt K, Yoo S, 
Akslen LA, Watnick RS (2009) Prosaposininhibits tumor metastasis via paracrine and endocrine stinu;ation of stromal p53 and Tsp-1. Proc Natl Acad Sci 106:12115-12120

Kaur B, Brat DJ, Devi NS, Van Meir EG (2005) Vasculostatin, a proteolytic fragment of brain angiogenesis inhibitor 1 , is an antiangiogenic and antitumorigenic factor. Oncogene 24:36323642

Kaur B, Cork SM, Sandberg EM, Devi NS, Zhang Z, Klenotic PA, Febbraio M, Shim H, Mao H, Tucker-Burden C, Silverstein RL, Brat DJ, Olson JJ, Van Meir EG (2009) Vasculostatin inhibits intracranial glioma growth and negatively regulates in vivo angiogenesis through a CD36- dependent mechanism. Cancer Res 69:1212-1220

Kazerounian S, Yee KO, Lawler J (2008) Thrombospondins in cancer. Cell Mol Life Sci 65:700-712

Kosfeld MD, Frazier WA (1993) Identification of a new cell adhesion motif in two homologous peptides from the $\mathrm{COOH}$-terminal cell binding domain of human thrombospondin. J Biol Chem 268:8808-8814

Kuehbacher A, Urbich C, Dimmeler S (2007) Targeting microRNA expression to regulate angiogenesis. Trends Pharmacol Sci 29:12-15

Kyriakides TR, Zhu Y-H, Smith LT, Bain SD, Yang Z, Lin MT, Danielson KG, Iozzo RV, LaMarca M, McKinney CE, Ginns EI, Bornstein P (1998) Mice that lack thrombospondin 2 display connective tissue abnormalities that are associated with disordered collagen fibrillogenesis, an increased vascular density, and a bleeding diathesis. J Cell Biol 140:419-430

Kyriakides TR, Tam JWY, Bornstein P (1999) Accelerated wound healing in mice with a disruption of the thrombospondin 2 gene. J Invest Dermatol 113:782-787

Kyriakides TR, Bornstein P (2003) Matricellular proteins as modulators of wound healing and the foreign body response. Thromb Haemost 90:986-992

Lawler J, Chao FC, Fang PH (1977) Observation on a high molecular weight platelet protein released by thrombin. Thromb Haemost $37: 355-357$

Lawler J, Slater HS, Coligan JE (1978) Isolation and characterization of a high molecular weight glycoprotein from human blood vessels. J Biol Chem 253:8609-8616

Lawler J, Hynes RO (1989) An integrin receptor on normal and thrombosthenic platelets that binds thrombospondin. Blood 74:2022-2027

Lawler J, Duquette M, Whittaker CA, Adams JC, McHenry K, DeSimone DW (1993) Identification and characterization of thrombospondin-4, a new member of the thrombospondin gene family. J Cell Biol 120:1059-1067

Lawler J, Sunday M, Thibert V, Duquette M, George EL, Rayburn H, Hynes RO (1998) Thrombospondin-1 is required for normal murine Pulmonary homeostasis and its absence causes pneumonia. J Clin Invest 101:982-992

Lawler J (2000) The functions of thrombospondin-1 and -2. Curr Opin Cell Biol 12:634-6340

Lawler J (2002) Thrombospondin-1 as an endogenous inhibitor of angiogenesis and tumor growth. J Cell \& Mol Med 6:1-12

Lawler J, Detmar M (2004) Tumor progression: the effects of thrombospondin-1 and -2. Int J Biochem \& Cell Biol 26:1038-1045

Lee NV, Sato M, Annis DS, Loo JA, Wu L, Mosher DF, Iruela-Arispe ML (2006) ADAMTS1 mediates the release of antiangiogenic polypeptides from TSP1 and TSP2. EMBO J 25:5270-5283

Liu A, Mosher DF, Murphy-Ullrich JE, Goldblum SE (2009) The counterahesive proteins, thrombospondin 1 and SPARC/osteonectin open the tyrosine phosphorylation-responsive paracellular pathway in pulmonary vascular endothelia. Microvas Res 77:13-20

Malek MH, Olfert IM (2009) Global deletion of thrombospondin increases cardiac and skeletal muscle capillarityand exercise capacity in mice. Exp Physiol 94:749-760
Margosio B, Marchetti D, Vergani V, Giavazzi R, Rusnati M, Presta M, Taraboletti G (2003) Thrombospondin 1 as a scavenger for matrix- associated fibroblast growth factor 2. Blood 102:4399 4406

McPherson J, Sage EH, Bornstein P (1981) Isolation and characterization of a glycoprotein secreted by aortic endothelial cells in culture. J Biol Chem 256:11330-11336

Mirochnik Y, Kwiatek A, Volpert OV (2008) Thrombospondin and apoptosis: molecular mechanisms and use for design of complementation treatments. Current Drug Targets 9:851-862

Mosher DF, Doyle MJ, Jaffe EA (1982) Synthesis and secretion of thrombospondin by cultured human endothelial cells. J Cell Biol 93:343-348

Newton CS, Loukinova E, Mikhailenko I, Ranganathan S, Gao Y, Haudenschild C, Strickland DK (2005) Platelet-derived growth factor receptor-beta (PDGFR-beta) activation promotes its association with the low density lipoprotein receptor-related protein (LRP). Evidence for co-receptor function. J Biol Chem 280:27872-27878

Nicosia RF, Tuszynski GP (1994) Matrix-bound thrombospondin promotes angiogenesis in vitro. J Cell Biol 124:183-193

Noh Y-H, Matsuda K, Hong Y-K, Kunstfeld R, Riccardi L, Koch M, Oura H, Dadras SS, Streit M, Detmar M (2003) An N-terminal $80 \mathrm{kDa}$ Fragment of human thrombospondin-2 inhibits vascular endothelial growth factor induced endothelial cell migration in vitro and tumor growth and angiogenesis in vivo. J Invest Derm 121:1536-1543

Oganesian A, Armstrong LC, Migliorini MM, Strickland DK, Bornstein P (2008) Thrombospondins use the VLDL receptor and a nonapoptotic pathway to inhibit cell division in microvascular endothelial cells. Mol Biol Cell 19:563-571

Oldberg A, Antonsson P, Lindblom K, Heinegård D (1992) COMP (cartilage oligomeric protein) is structurally related to the thrombospondins. J Biol Chem 267:23346-23350

Panetti TS, Chen H, Misenheimer TM, Getzler SB, Mosher DF (1997) Endothelial cell mitogenesis induced by LPA: inhibition by thrombospondin-1 and thrombospondin-2. J Lab Clin Med 129:208-216

Qian X, Wang TN, Rothman VL, Nicosia RF, Tuszynski GP (1997) Thrombospondin-1 modulates angiogenesis in vitro by upregulation of matrix metalloproteinase- 9 in endothelial cells. Exp Cell Res 235:403-412

Rastinejad F, Polverini PJ, Bouck NP (1989) Regulation of the activity of a new inhibitor of angiogenesis by a cancer suppressor gene. Cell 56:345-355

Raugi GJ, Mumby SM, Abbott-Brown D, Bornstein P (1982) Thrombospondin: synthesis and secretion by cells in culture. $\mathrm{J}$ Cell Biol 95:351-354

Rege TA, Stewart J Jr, Dranka B, Beneviste EN, Silverstein RL, Gladson CL (2009) Thrombospondin-1-induced apoptosis of brain microvascular endothelial cells can be mediated by TNF-R1. J Cell Physiol 218:94-103

Ren B, Song K, Parangi S, Jin T, Ye M, Humphreys R, Duquette M, Zhang X, Benhaga N, Lawler J, Khosravi-Far R (2009) A double hit to kill tumor and endothelial cells by TRAIL and antiangiogenic 3TSR. Cancer Res 69:3856-5865

Ribeiro SM, Poczatek M, Schultz-Cherry S, Villain M, Murphy-Ullrich JE (1999) The activation sequence of thrombospondin-1 interacts with the latency-associated peptide to regulate activation of latent transforming growth factor- $\beta$. J Biol Chem 274:13586-13593

Roberts DD (1996) Regulation of tumor growth and metastasis by thrombospondin-1. FASEB J 10:1183-1191

Rodriguez-Manzaneque JC, Lane TF, Ortega MA, Hynes RO, Lawler J, Iruela-Arispe ML (2001) Thrombospondin-1 suppresses spontaneous tumor growth and inhibits activation of matrix metalloproteinase-9 and mobilization of vascular endothelial growth factor. Proc Natl Acad Sci 98:12485-12490 
Rusk A, McKeegan E, Haviv F, Majest S, Henkin J, Khanna C (2006a) Preclinical evaluation of antiangiogenic thrombospondin-1 peptide mimetics, ABT-526 and ABT-510, in companion dogs with naturally occurring cancers. Clin Cancer Res 12:7444-7455

Rusk A, Cozzi E, Stebbins M, Vail D, Graham J, Valli V, Henkin J, Sharpee R, Khanna C (2006b) Cooperative activity of cytotoxic chemotherapy with antiangiogenic thrombospondin-1 peptides, ABT-526, in pet dogs with relapsed lymphoma. Clin Cancer Res 12:7456-7464

Sage H, Pritzl P, Bornstein P (1981) Secretory phenotypes of endothelial cells in culture: comparison of aortic, venous, capillary, and corneal endothelium. Arteriosclerosis 2:427-442

Sage EH, Bornstein P (1991) Extracellular proteins that modulate cellmatrix interactions: SPARC, tenascin and thrombospondin. J Biol Chem 266:14831-14834

Schultz-Cherry S, Chen H, Mosher DF, Misenheimer TM, Krutzsch HC, Roberts DD, Murphy-Ullrich JE (1995) Regulation of transforming growth factor- $\beta$ activation by discrete sequences of thrombospondin 1. J Biol Chem 270:7304-7310

Short SM, Derrien A, Narsimhan RP, Lawler J, Ingber DE, Zetter BR (2005) Inhibition of endothelial cell migration by thrombospondin-1 type 1 repeats is mediated by $\beta_{1}$ integrins. J Cell Biol 168:643-653

Silverstein RL, Febbraio M (2007) CD36-TSP-HRGP interactions in the regulation of angiogenesis. Curr Pharmaceut Design 13:3559-3567

Simantov R, Febbraio M, Silverstein RL (2005) The antiangiogenic effect of thrombospondin-2 is mediated by CD36 and modulated by histidine-rich glycoprotein. Matrix Biol 24:27-34

Södersten F, Elman S, Schmitz M, Paulsson M, Zaucke F (2006) Thrombospondin- 4 and cartilage oligomeric matrix protein form heterooligomers in equine tendon. Conn Tiss Res 47:85-91

Staniszewska I, Zavefi S, Del Valle L, Oliva I, Rothman VL, Croul SE, Roberts DD, Mosher DF, Tuszynski GP, Marcinkiewicz C (2007) Interaction of $\alpha 9 \beta 1$ integrin with thrombospondin-1 promotes angiogenesis. Cir Res 100:1308-1316

Stenina OI, Byzova TV, Adams JC, McCarthy JJ, Topol EJ, Plow EF (2004) Coronary artery disease and the thrombospondin single nucleotide polymorphisms. Int J Biochem Cell Biol 36:10131030
Taraboletti G, Roberts D, Liotta LA, Giavazzi R (1990) Platelet thrombospondin modulates endothelial cell adhesion, mobility, and growth: a potential angiogenesis regulatory factor. J Cell Biol 111:765-772

Taraboletti G, Belotti D, Borsotti P, Vergani V, Rusnati M, Presta M, Giavazzi G (1997) The 140-kilodalton antiangiogenic fragment of thrombospondin binds to basic fibroblast growth factor. Cell Growth and Differ 8:471-479

Taraboletti G, Morbidelli L, Donnini S, Parenti A, Harris J, Granger Giavazzi R, Ziche N (2000) The heparin binding $25 \mathrm{kDa}$ fragment of thrombospondin-1 promotes angiogenesis and modulates gelatinase and TIMP-2 production in endothelial cells. FASEB J 14:1674-1690

Tokunaga T, Nakamura M, Oshika Y, Abe Y, Ozeki Y, Fukushima Y, Hatanaka H, Sadahiro S, Kijima H, Tsuchida T, Yamazaki H, Tamaoki N, Ueyama Y (1999) Thrombospondin 2 expression is correlated with inhibition of angiogenesis and metastasis of colon cancer. Brit J Cancer 79:354-359

Tolsma SS, Volpert OV, Good DJ, Frazier WA, Polverini PJ, Bouck N (1993) Peptides derived from two separate domains of the matrix protein thrombospondin-1 have anti-angiogenic activity (1993). J Cell Biol 122:497-511

Tuszynski GP, Nicosia RF (1996) The role of thrombospondin-1 in tumor progression and angiogenesis. BioEssays 18:71-1876

Volpert OV, Tolsma SS, Pellerin S, Feige JJ, Chen H, Mosher DF, Bouck N (1995) Inhibition of angiogenesis by thrombospondin 2. Biochem Biophys Res Commun 217:326-332

Vos HL, Devarayalu S, de Vries Y, Bornstein P (1992) Thrombospondin 3 (Thbs3), a new member of the thrombospondin gene family. J Biol Chem 267:12192-12196

Wang S, Wu Z, Sorenson CM, Lawler J, Sheibani N (2003) Thrombospondin-1-deficient mice exibit increased vascular density during retinal vascular development and are less sensitive to hyperoxia- mediated vessel obliteration. Develop Dyn 228:630-642

Yang Z, Strickland DK, Bornstein P (2001) Extracellular matrix metalloproteinase 2 levels are regulated by the low density lipoprotein related scavenger receptor and thrombospondin 2. J Biol Chem 276:8403-8408 